\title{
Characteristics of Continuing Professional Learning Provisions for School Mathematics Teachers in Zimbabwe
}

\author{
David Kufakwami Mtetwa ${ }^{1}$, Zakaria Ndemo ${ }^{2,}$, Evelyn Maturure $^{3}$, Bernadette Chabongora ${ }^{4}$ \\ ${ }^{1}$ Department of Science and Mathematics Education, University of Zimbabwe, Harare, Zimbabwe \\ ${ }^{2}$ Department of Science and Mathematics Education, Bindura University of Science Education, Bindura, Zimbawe \\ ${ }^{3}$ Mathematics Unit, Zimbabwe School Examination Council, Harare, Zimbabwe \\ ${ }^{4}$ Catholic Diocese of Gweru, Gweru, Zimbabwe
}

Email address:

zndemo@gmail.com (Z. Ndemo)

${ }^{*}$ Corresponding author

\section{To cite this article:}

David Kufakwami Mtetwa, Zakaria Ndemo, Evelyn Maturure, Bernadette Chabongora. Characteristics of Continuing Professional Learning Provisions for School Mathematics Teachers in Zimbabwe. International Journal of Secondary Education. Vol. 7, No. 3, 2019 , pp. 77-88. doi: 10.11648/j.ijsedu.20190703.13

Received: May 31, 2019; Accepted: July 25, 2019; Published: September 19, 2019

\begin{abstract}
In Zimbabwe, as elsewhere, lifelong professional learning is now a major expectation for mathematics teachers. The study investigated the nature of opportunities for professional learning accessible to mathematics teachers in Zimbabwe, focusing on three themes of range and style of learning provisions, support systems, and monitoring and valuing of the learning. Data were gathered from a sample of 94 mathematics teachers, 4 mathematics inspectors, 10 ministry district officers, 4 ministry provincial officers, 16 school principals, 6 independent professional development providers, and 6 ministry national head office personnel who were all purposively approached on considerations of availability, accessibility, willingness, and being potentially key informants in relation to teacher professional development matters. Structured interviews and a questionnaire were used to elicit informants' experiences of and perspectives on the themes. The main findings were that (a) further teacher professional learning activities came mainly in form of formally orchestrated workshops in the field and programmes in tertiary institutions; and much less in forms such as meetings, discussion groups, exchange visits, and seminars, (b) supportive policy guidelines for such learning existed though not buttressed by adequate material provisions for meaningful functioning, and (c) while the system had no dedicated formal quality monitoring and evaluation schemes specific for continuing professional learning, there were indications of high teacher motivation for exploiting learning opportunities. The findings reveal underutilization of informal uncertified learning platforms such as peer co-learning or e-chat groups, and possible conflicts of expectations and aspirations between continuing professional learning providers and teacher clients in the Zimbabwean system.
\end{abstract}

Keywords: Continuing Professional Development, Mathematics Teacher Learning, Teacher Support Systems, Teacher Motivation, Teacher Values

\section{The Research Problem and Theoretical Considerations}

\subsection{Introduction}

In the teaching profession it has become almost mandatory to continue with professional learning in the post-initial training life of the teacher. Life-long professional learning as it is widely called - has become a necessity due in part to information explosion and the associated rapid generation and dissemination of the knowledge, alongside changes brought about through continuous transformation of both new and old knowledge. While this kind of learning by professionals in practice-also referred to as continuing professional development (CPD) or continuous professional learning (CPL) - had largely been left to chance or incidental learning, more recently some countries have begun to acknowledge the need to systematize and formalize CPD for 
their teachers, for example, the CPD Unit of University of Namibia [1]. One major issue that arises in this regard is a consideration of the nature of forms (a matter of structure), formats (a matter of style), and outcomes (a matter of content) that CPD learning for teachers in general and mathematics teachers in particular might entail in specific operational environments. This paper aims to contribute to this debate based on a study conducted in the mould of 'needs analysis' to understand the status quo of things in relation to form and style of CPD learning for Zimbabwean mathematics teachers.

A basic background feature of the Zimbabwean education system in the last three decades is the pronounced shift in thrust of aspired goals from that of attaining quantitative adequacy in the 1980s and qualitative adequacy in the 1990s, to equity and efficiency adequacy in the 2000s in cumulative fashion [see Mtetwa, Chabongora, Ndemo, and Maturure [2] for a fuller description of this phenomenon along with the attenuating effects of the catastrophic national economic meltdown of $2000-2010$ ]. The essential point to draw from the SEITT [3] document and Chavunduka [4] about these focus-shifts is that the quality focus of the 1990s looked to CPD of science and mathematics teachers, especially at secondary school phase, as the answer to the problem of raising quality student learning outcomes in those subjects. Abreh [5] argues that no amount of access, equity and equality can translate into quality education automatically. Hence, there is need to examine CPD provision inwardly to determine the kinds of its practices. But how was CPD learning of teachers channeled to support the qualityoutcome thrust and what was the status quo then in the wake of the economic collapse, that is to say, during the second decade of the 2000 s that is widely regarded as the recovery period? Although during that period some CPD-related activity had been taking place to varying degrees and in various forms as noted by Mtetwa et. al. [2], there is still need to understand how CPD education for mathematics teachers in Zimbabwe functions as a system. The authors are not aware of a study conducted to that effect apart from the one reported in this paper that was motivated in part by similar studies that ran at the same time in nine other countries. This set of studies was designed to compare and share promising practices in mathematics teacher continuing professional development for purposes of enhancing quality learning outcomes in students.

The study was guided by the main question: What is the nature of CPD activity for mathematics teachers in Zimbabwe? and focus questions (1) What provisions for continuing professional learning of mathematics teachers are found in Zimbabwe? [Seeking to identify the range of opportunities for CPD learning]; (2) What kinds of CPD support do mathematics teachers receive to sustain the learning provisions? [Seeking to characterize the style of support mechanisms]; and (3) What monitoring measures are used to regulate the quality of the CPD activities? [Seeking to understand the strategies used to appraise CPD learning processes and outcomes]. Based on Gomba's [6] understanding of CPD that is open to include any kind of learning activity, formal or informal, that is engaged by the teacher beyond initial training, with an expressed objective of impacting positively on the teacher's practice, the present study used an interview and questionnaire guided descriptive survey of key informants across different levels of the educational system.

In the next section a briefly review of some reported studies on models and formats of CPD is made, followed by a description of the data gathering processes and results obtained. Conclusions based on the results are made at the end implications for quality aspects of the CPD system as it relates to mathematics teachers considered.

\subsection{Some Perspectives on Professional Development}

To begin with the use of term continuing professional development (CPD) is put into perspective. M. Si [7] defines $\mathrm{CPD}$ as the process of engaging in continuous learning as a basis to strengthen knowledge, skills, and ability to execute professional duties with confidence. In addition to enhancing knowledge and skills, Abreh [5] suggests that CPD must be conceived as a deeper, wider and long-term process intended to enhance more importantly mathematics teachers' thinking. Such thinking need not be restricted to their work roles but should allow CPD participants to embrace new roles and responsibilities. Individuals who interact among each other with different roles, experiences, and expertise have been described by WeiBrenieder, Roeskin-Winter, Schueler, Binner, and $\mathrm{Bl} \ddot{o}$ meke [8] as multipliers. Mathematics teachers and CPD providers can be seen as 'multipliers' because they interact in professional learning processes through, for instance, sharing their knowledge, often collaboratively, in specific CPD activities according to Roesken-Winter, Hoyles, and Blomeke [9] Thus, a major aim for engaging in CPD learning is to raise an individual's selfefficacy, defined by Bandura [10] as "belief in one's capabilities to organize and execute the courses of action to produce given attainments." Such capabilities include the ability to analyze and interpret students' thinking as suggested by Sapt et al. [11]. Abreh [5] writes that improved interpretation of practice in turn influences learning outcomes. The development of self-efficacy related to 'multiplying' CPD is significant because teachers with higher levels of self-efficacy have been found to compose their teaching in more challenging ways, and to demonstrate a tendency to provide more student support as observed by WeiBrenieder et. al. [8]. The idea of self-efficacy as a predictor for the role of multipliers in CPD was relevant in this study that also explored mathematics teacher motivations for doing CPD activities in Zimbabwe.

Varga-Atkins, O'Brien, Burton, Campel, and Qualter [13] conceptualize CPD in terms of learning opportunities, both formal and informal, that will enable professionals to improve their teaching. Formal and informal learning opportunities involved in CPD draw from intellectual, personal and social domains. The CPD perspective adopted in this study is akin to the idea of professional learning in the sense of CPD being seen as an on-going process, often non- 
linear, rather than outcome of linear one-off training events. In this view CPD learning should have a focus on professional renewal through opportunities to rethink and renew practices, and in so doing multipliers become reflective practitioners in the sense suggested by Mansour, El-Delhaidy, Alshamrani, and Aldahmash [12]. This broader interpretation of CPD has the potential to influence CPD providers to embrace the notion of shift in reform ownership where they can work with teachers as partners who can take a lead in their own professional development rather than as just trainees who digest what is offered to them.

\subsection{Models and Formats of CPD}

According to Sabah, Fayez, Alshamrani, and Mansour [14] one way to characterize the diversity of CPD models is by determining whether the educational system is centralized or non-centralized. For example, study in Saudi Arabia, Mansour et al [12] showed that mathematics teachers dealt with CPD content that was not commensurate with their professional needs as learners. Such mismatch reflects a CPD model where a centralized orientation is more dominant. Similar mismatches between teachers' CPD needs and those presented by providers have been reported from an Indonesian study by M. Si [7]. In decentralized systems such as that of Denmark, schools are responsible for organizing CPD activities that meet the needs of teachers in particular settings. On the other hand in centralized educational systems - like those found in Turkey and Saudi ArabiaCPD learning is typically a top-down affair. Mansour et al. [12] pointed out that a major flaw of the latter form of CPD lies not only in its disregard for the challenges and opportunities in teachers' local contexts but also in its failure to pay attention to the voices and perspectives of the individuals taking part in the CPD. In the same study in Saudi Arabia, Mansour et al. [12] suggest that professional learning can be effective when teachers are able to talk with each other about CPD programmes in their school settings.

Another CPD model described by Sachs [15] is based on three building metaphors, namely, 'retooling', 'remodeling,' and 'revitalizing.' Regarding CPD as 'retooling,' the focus of CPD learning is on practical view of teaching with an emphasis on relevance and immediate application in classrooms. CPD learning as 'remodeling' has its prime objective as reinforcing the practical approach to teaching without changing teachers' beliefs and yet a broad perspective of CPD should encompass the emotional domain. The role of the teacher in remodeling is to 'entertain' students as teachers are viewed as performers. It is important to observe here in both 'retooling' and 'remodeling' CPD formats; teachers are seen as uncritical consumers of knowledge who are mainly concerned with improving specific skills that relate to classroom practice. Finally, Sach's model of CPD as 're-vitalizing' encourages teachers to connect to other 'multipliers,'leading to spillover effects of CPD through collegial interactions and professional learning collaborations. These interactions eventually lead to changes in teachers' professional practice (actions) as well as their thinking about practice.

Kennedy [16] proposes a CPD model based on professional autonomy of the teachers. Kennedy's model has three broad categories based on a dimension of locus control for the learning. The first main category, the transmission, is where teachers have low control over their professional learning. Training and award bearing are subcategories of the transmission class where training compares with re-tooling in Sachs' model. Mtetwa et. al. [2] observed that award bearing as sub-category in the Kennedy model is reflected strongly in the Zimbabwean context where motivation for engaging in professional learning is social and economic upgrading. The second main category, the transitional category, encompasses orientations such as community of practice and coaching/mentoring and is the middle level category where teachers have control over CPD learning. Finally, Sabah et al. [14] assert that the transformative category has orientations such as action research and even allows more professional autonomy for teachers. Capacity for professional autonomy increases as one moves from the transmission through the transitional to the transformative level of professional learning.

Turbill cited in quoted in Vargas-Atkins et. al. [13] provides an alternative model about how professional learning occurs. Turbill asserts that learning takes place as a result of interactions between 'inside' and 'outside' knowledge. The 'inside' knowledge comprises two knowledge domains: 'personal theory' and 'personal theory in practice,' while the 'outside knowledge' consists of the 'theory of others' and the 'theory of others in practice.' For Turbill, the intersection between the four knowledge domains is an essential source of professional learning and the interrelatedness crucial for life-long learning. Turbill in Vargas-Atkins et. al. [13] explains:

When teachers have a sense of their needs and opportunities to access information ('inside-out learning'), they are placed in a position to interact with and engage in new knowledge ('outside-out learning') and to take from it that which they need. This process of transforming new knowledge with old knowledge through the use interrelated learning conditions of reflection, sharing, and collaboration, allows the teachers to make the knowledge, their own. It is the synergy created through the interplay of these conditions that underpins sustained professional learning (p. 244).

This model suggests that the intersection, which is assisted by a facilitator, is an important space for professional learning where CPD processes such as collaboration, sharing, and reflection take place. Turbill's model raises the need for a facilitator in forming the intersection of the four knowledge domains. Such a facilitator would constitute an important node in a CPD support system. Turbill's model, with its emphasis on interaction, resonates well with a socio-cultural perspective on professional learning

\subsection{Socio-Cultural Perspective}

Joubert, Back, De Geest, Hirst, and Sutherland [17] define the socio-cultural perspective as an understanding that all 
human activity, including professional learning of mathematics teachers, is historically, socially, culturally, and temporally situated. Joubert et. al. [17] explain that professional learning can in this sense be viewed in terms of a learning landscape in which there is interaction of several elements such as students' perspectives, content, resources, and socio and economic micro and political contexts Mokhele and Jita [18] suggest that one factor that contributes to teacher dissatisfaction with professional development is that the majority of CPD programmes do not take into account factors that motivate teachers to engage in CPD. Hence, the socio-cultural perspective emphasizes the need to pay attention to the context or sites of professional learning together with due considerations for content, and processes in which mathematics teachers engage during CPD. The objective of CPD models discussed above is to provide opportunities for teachers to become involved in processes of change. Hence, the analytic framework was also influenced by the idea that teachers' professional learning is influenced by personal motives, beliefs, theories and experience and their perceptions of CPD opportunities. In the final the section it is noted that the main goal of CPD learning should be to build a wide and autonomous capacity for teachers to learn and concomitantly improve teaching.

\section{Research Methodology}

\subsection{Data Generation for the Study}

The main question that the study investigated was "What is the nature of CPDs provided for mathematics teachers in Zimbabwe?" This research was part of a ten nation study aimed at exchanging ideas on promising practices in CPD for improving the quality of mathematics education in participating countries. The objective was to understand how mathematics teachers and professional development providers interact with each other in their engagements with CPD to enhance or suppress opportunities for further learning. When examining patterns of human' behaviour and experience as is done in this study, the researchers opted for qualitative data generation strategies that typically generate rich information as recommended by Macmillan and Schumacher [19]. Qualitative approach emphasizes the importance of letting the lived experiences - in this case that of teachers and the providers of CPD programmes such as ministry education, tertiary institutions, and nongovernmental organizations - of the participants tell their stories in their own words and actions as suggested by Denzin and Lincoln [20].

\subsection{Population and Sample}

The population of interest for this study comprised all mathematics teachers, mathematics inspectors, school heads (principals), officers responsible for CPD at district, provincial and national levels and institutions or organizations associated with teachers in CPD work in the 4 provinces used by the study. Purposive sampling was used in selecting informants based on their involvement with CPD activity in Zimbabwe. Data were collected from interviews with 16 school heads, 4 mathematics subject inspectors, 10 district officials, 4 provincial officers, 6 national head office staff in the ministry and 6 independent providers. Questionnaires were administered to 94 practicing teachers at the time engaged in one form of CPD learning or another. Table 1 summarizes the sample characteristics

Table 1. Data Sources.

\begin{tabular}{|c|c|c|c|c|}
\hline Source & Population (estimate) & Sample used & Instrument & Remarks/considerations \\
\hline Ministry Head officers & Over 10 & 6 & Interview & Some key informants \\
\hline Provincial officers & 10 provinces & 4 & Interview & Opportunity \\
\hline District officers & 52 districts & 10 & Interview & Availability and access \\
\hline Maths inspectors & Over 20 & 4 & Interview & Few in post then \\
\hline School heads & Hundreds in 4 provinces used & 16 & Interview & Availability and access \\
\hline CPD providers & Over 20 identifiable & 6 & Interview & Access \\
\hline Teachers & thousands in the provinces used & 94 & Questionnaire & Opportunity \\
\hline
\end{tabular}

Informants were selected on account of availability and accessibility to the researchers. Questionnaire was administered to teachers while interviews were used for the

other sources. Table 2 shows some characteristics of the teacher sample used.

Table 2. Teacher Profile $(n=94)$.

\begin{tabular}{lllll}
\hline Gender & Experience (years) & Qualifications & Number of CPDS done & Levels taught \\
\hline & Under 5 (11) & Cert/Dip (39) & Over 5 (0) & Primary (0) \\
Female (17) & 6 to 10 (8) & Degree (14) & $3-5(0)$ & Secondary (32) \\
Male (40) & 11 to 15 (4) & Post grad (1) & $0-2,(33)$ & Tertiary (1) \\
Total 57 & Over 16 (10) & 54 & 33 & 33 \\
\hline
\end{tabular}

It can be seen from the table that of the 57 (out of 94) teachers who indicated their gender, there were twice as many males as females. There was only a sprinkling of teacher training college lecturers among the teacher respondents. All respondents indicated they had experienced less than 3 CPDs, depending on what counted as CPD experience for them, of course. 


\subsection{Process and Analysis}

A questionnaire for teachers and a semi-structured interview schedules for the other data sources were developed at a workshop by research team leaders from the ten countries taking part in the study and piloted earlier in the different countries to contextualize them. The questionnaire and interview guides had a common basic structure but contextualized for country and data source type, with items eliciting informants' responses on their experiences on the three research question themes of nature of CPD activity, support system, and monitoring and valuation of the learning [see Mtetwa, et al. [2]) for a detailed description of the instruments].

The piloting process, reported in detail in Mtetwa et. al. [2], informed the researchers that for the main study

It was not practicable to get additional information from observations of CPD activity that had been originally intended, hence, the observation schedule was not used.

The interviewer had to be adept at modifying framing interview guide items on the spot and short hand recording of field notes in order to get elaborated responses, especially in cases where an informant declined to be audio-tape recorded.

The researchers had to be content with gaining access to 'opportunity informants,' considering that some of the potential informants were hardly available on account of exceedingly busy office work schedules, even with advanced booking arrangements.

The authors shared the information gathering task in the four research provinces (selected on accessibility considerations) and conducted the fieldwork over four months. Analysis of the data happened in several sequential phases

First, each researcher transcribed all audio-taped data in interview summary format and collated with related (by informant) data

Next, the researchers met and categorized all items on each instrument into the subthemes of policy issues, support schemes, CPD activities, suggestions for improvement, teacher motivation, and monitoring and value considerations. This was not difficult to do as the subthemes had been foundational in the construction of the instruments in the first place

The third phase involved each researcher using that analytic framework to process his/her raw data

Next, the processed data from the 4 researchers were integrated and analyzed by data source and subtheme to produce a condensed and consolidated overall data matrix (not presented here due to its large size)

This was followed by examining emerging patterns within subthemes and across data sources at once in relation to each of the three research questions as captured in Tables 3, 4, and 5 in the next section. The subthemes of CPD activities and suggestions for improvement responded to research question one on nature and style of CPD provisions, policy issues and support schemes subthemes to research question two on nature of support for CPD learning, and teacher motivational and assessment of learning subthemes to research question three on monitoring and valuation of CPD activity. Conclusions and recommendations are drawn from analysis of Tables 3, 4, and 5 in relation to respective focus questions

All the instruments used for this main study had been validated in the pilot study Mtetwa et. al. [2]. In addition, following Maree [21] the use of multiple data sources, and the sequential data distillation analytic procedure deployed in the main study, with cross-checks among the four researchers at each phase of the entire process, contributed to strengthening the validity and trustworthiness of the findings and conclusions drawn from them.

\section{Results}

Results of the study are presented in tables by research (focus) question to enhance clarity. Table 3 summarizes informant responses relating to research question one about activities and suggestions on improving them.

\subsection{Research Question One: Nature of CPD Activity}

Table 3. Annotated summary of informant responses about activities and suggestions on improving them.

\begin{tabular}{|c|c|c|c|c|c|}
\hline Source & Head office $(n=6)$ & Provincial $(n=4)$ & District $(n=10)$ & Subject Inspector $(n=4)$ & School Head $(n=16)$ \\
\hline Activity type & $\begin{array}{l}\text { At all levels (national to } \\
\text { school); Workshops, } \\
\text { self-initiated } \\
\text { programmes for higher } \\
\text { qualifications, other } \\
\text { regular short courses } \\
\text { (admin initiated) in and } \\
\text { out of country; Special } \\
\text { programmes, } \\
\text { conferences, seminars }\end{array}$ & $\begin{array}{l}\text { Mostly workshops } \\
\text { initiated, executed and } \\
\text { facilitated within system; } \\
\text { Some special projects here } \\
\text { and there (e.g. SEITT } \\
\text { etc.); Donor supported } \\
\text { Done in term time } \\
\text { strategically to minimize } \\
\text { disruption }\end{array}$ & $\begin{array}{l}\text { Workshops, meetings } \\
\text { (subject, CPD), } \\
\text { discussion groups; These } \\
\text { are initiated by } \\
\text { inspectorate or admin } \\
\text { and are done during term } \\
\text { time } \\
\text { Those initiated by } \\
\text { teaches are done during } \\
\text { weekend or holidays }\end{array}$ & $\begin{array}{l}\text { Mostly workshops but } \\
\text { can have exchange visits } \\
\text { among schools for } \\
\text { programmes and higher } \\
\text { qualification }\end{array}$ & $\begin{array}{l}\text { Mostly 1-3day } \\
\text { workshops; demo } \\
\text { lessons, courses for } \\
\text { higher qualifications, } \\
\text { workshops mostly } \\
\text { school initiated }\end{array}$ \\
\hline $\begin{array}{l}\text { Suggestions } \\
\text { for } \\
\text { improvement }\end{array}$ & $\begin{array}{l}\text { Increase funding and } \\
\text { material work conditions } \\
\text { (e.g. salaries); } \\
\text { Recognize CPD through } \\
\text { points; Professionalize } \\
\text { teaching; Share } \\
\text { sponsorship with self; }\end{array}$ & $\begin{array}{l}\text { CPD learning to be } \\
\text { legitimised through } \\
\text { linkages to higher } \\
\text { education benchmarks; } \\
\text { CPD dedicated fund from } \\
\text { ministry; Link teacher } \\
\text { CPD to management CPD }\end{array}$ & $\begin{array}{l}\text { Maintain cluster } \\
\text { workshops; } \\
\text { Give certificates of } \\
\text { attendance }\end{array}$ & $\begin{array}{l}\text { Need for ministry } \\
\text { dedicated funding } \\
\text { though local organs } \\
\text { should continue fund } \\
\text { raising; Needs analysis } \\
\text { should be continuous }\end{array}$ & $\begin{array}{l}\text { CPD budget; } \\
\text { Multimode approach } \\
\text { to CPD, e.g., e- } \\
\text { learning in addition to } \\
\text { face to face; } \\
\text { Open-mindedness of } \\
\text { teachers; }\end{array}$ \\
\hline
\end{tabular}




\begin{tabular}{|c|c|c|c|c|c|}
\hline Source & Head office $(n=6)$ & Provincial $(n=4)$ & District $(n=10)$ & Subject Inspector $(n=4)$ & School Head $(n=16)$ \\
\hline & Use bottom-up approach & $\begin{array}{l}\text { for scaffolding purposes } \\
\text { Account CPD to self and } \\
\text { funders }\end{array}$ & & & $\begin{array}{l}\text { Involve teachers in } \\
\text { CPD planning; } \\
\text { International exposure, } \\
\text { Learning oriented } \\
\text { school environment; } \\
\text { Diarize a coordinated } \\
\text { menu of CPD } \\
\text { activities }\end{array}$ \\
\hline
\end{tabular}

\begin{tabular}{|c|c|c|}
\hline Source & =6) & $\operatorname{acher}(n=94)$ \\
\hline Activity type & $\begin{array}{l}\text { Workshops and programmes } \\
\text { for higher qualifications } \\
\text { mostly, less conferencing, more } \\
\text { emphasis on subject matter and } \\
\text { professional knowledge } \\
\text { (pedagogy upgrading) and less } \\
\text { professional development (on } \\
\text { life-long learning capacity) in } \\
\text { its broad sense }\end{array}$ & $\begin{array}{l}\text { Most CPD activities come in the form of courses in programmes at institutions of higher education for } \\
\text { formal academic /professional qualifications (12 responses) these are normally undertaken during } \\
\text { school holidays in block release/part time format. ( } 39 \text { responses). Those undertaken even during } \\
\text { school learning time are full time courses (for which one needs study leave from the ministry) ( } 27 \\
\text { responses). Such activities also include workshops, conferences, seminars, peer discussions, } \\
\text { professional development meetings. } \\
\text { [The thrust of all the CPD activities is pedagogic knowledge in the main but in conjunction with } \\
\text { content knowledge (maths concepts) and PCK (teaching the concepts) in relation to curricular } \\
\text { knowledge e.g. syllabus interpretation). Assessment (test construction and marking feature as } \\
\text { prominently as ICT. There is low, otherwise insignificant, mention of institutional materials } \\
\text { development, research, or problem solving as CPD focus issues. Some teachers indicated having } \\
\text { never participated in any CPD, yet they were enrolled in an in-service BEd programme at the time] }\end{array}$ \\
\hline $\begin{array}{l}\text { Suggestions } \\
\text { for } \\
\text { improvement }\end{array}$ & $\begin{array}{l}\text { CPD to be well funded and } \\
\text { requires a management system } \\
\text { to client driven within a life- } \\
\text { long learning frame work, work } \\
\text { environment to be inspiriting } \\
\text { worker }\end{array}$ & $\begin{array}{l}\text { Suggestions consist in part in reducing the impact/interference of the constraining challenges, e.g., } \\
\text { Inject funding into the CPD learning } \\
\text { Provide associated learning materials } \\
\text { Make CPD inclusive and extensive } \\
\text { Activities to be better planned and organised, (preparedness, calendared) } \\
\text { Provide maths specialist infrastructure }\end{array}$ \\
\hline $\begin{array}{l}\text { Overall } \\
\text { researcher } \\
\text { observations }\end{array}$ & \multicolumn{2}{|c|}{$\begin{array}{l}\text { Short duration workshops during term time, occasionally longer duration during school holidays. These are usually initiated by the } \\
\text { school, ministry organ, subject/professional association or donor partner. Short courses or longer course programmes done often during } \\
\text { holidays are mostly self initiated and for obtaining higher qualifications. School initiated activities are typically school sponsored, } \\
\text { while own/other initiated activities can be shared (with willing supporter) or be self-sponsored. } \\
\text { Seminars, peer lessons, conferences, exchange visits, meetings, group discussions, may happen here and there per opportunity } \\
\text { Suggestions are mostly on availing CPD funding, improving coordination and general efficiency of managing the activities, and } \\
\text { acknowledging CPD learning by ways other than with paper qualifications } \\
\text { Almost all activities take formal structure and operational characteristics, hardly any are of informal CPD learning platforms. }\end{array}$} \\
\hline
\end{tabular}

Table 3 indicates that some of the CPD activities are in the form of seminars, workshops, conferences and peer lessons and that almost all activities take formal structure. Also, longer activities take place during school holidays while shorter ones are done during school days. Table 4 pertains to the second research question on support system.

\subsection{Research Question Two: Nature of Support for CPD Activity}

Table 4. Annotated summary of informant responses about related policy and support arrangements.

\begin{tabular}{|c|c|c|c|c|c|}
\hline Source & Head office $(n=6)$ & Provincial $(n=4)$ & District $(n=10)$ & Subject Inspector $(n=4)$ & School Head $(n=16)$ \\
\hline $\begin{array}{l}\text { On } C P D \\
\text { policy }\end{array}$ & $\begin{array}{l}\text { Unanimous Yes, policy } \\
\text { translates from national } \\
\text { government vision for HR } \\
\text { development through higher } \\
\text { qualification to deliver quality } \\
\text { and relevant education }\end{array}$ & $\begin{array}{l}\text { Yes policy is there } \\
\text { but unfamiliar with } \\
\text { it. Evidence of } \\
\text { existence include } \\
\text { structures (HR), } \\
\text { activities (trainings) }\end{array}$ & $\begin{array}{l}\text { Yes at national level but } \\
\text { may not be aware of it. } \\
\text { There is a belief policy } \\
\text { exists (comes from linking } \\
\text { practices at district and } \\
\text { national levels (MDL) that } \\
\text { are consistent with } \\
\text { existence of policy }\end{array}$ & $\begin{array}{l}\text { All say national policy } \\
\text { covers CPD though } \\
\text { schools can have their } \\
\text { own }\end{array}$ & $\begin{array}{l}\text { The majority of school } \\
\text { heads say there is a } \\
\text { policy that filters from } \\
\text { higher levels } \\
\text { Some are doubtful of the } \\
\text { existence of a policy to } \\
\text { the extent of believing } \\
\text { there is none }\end{array}$ \\
\hline $\begin{array}{l}\text { Support } \\
\text { possibilities }\end{array}$ & $\begin{array}{l}\text { National fiscus allocation for } \\
\text { capacity building in all } \\
\text { ministries though budget is } \\
\text { small (in principle it is there); } \\
\text { Supplemented by partnerships } \\
\text { of donors or foreign country } \\
\text { agreements and parents at } \\
\text { ground level (through } \\
\text { statutory instrument BSPZ); } \\
\text { Mechanism in place for self- } \\
\text { initiated CPD (MDL) }\end{array}$ & $\begin{array}{l}\text { Inadequate to no } \\
\text { funding from } \\
\text { ministry for desired } \\
\text { activity [ } a \\
\text { paradox]; } \\
\text { Schools (funds and } \\
\text { infrastructure) and } \\
\text { donors (expertise } \\
\text { and material); } \\
\text { Ministry gives } \\
\text { permission }\end{array}$ & $\begin{array}{l}\text { No central funding gets to } \\
\text { district level; Self support } \\
\text { (schools) with levies } \\
\text { managed at district level } \\
\text { by BSPZ; Strong district } \\
\text { moral support to schools } \\
\text { Donors occasionally } \\
\text { mostly in kind and other } \\
\text { form of facilitation }\end{array}$ & $\begin{array}{l}\text { Ministry supports } \\
\text { through facilitations } \\
\text { however local organs } \\
\text { support through levies } \\
\text { and encouragement } \\
\text { (emotional) }\end{array}$ & $\begin{array}{l}\text { Support from school is } \\
\text { mostly } \mathrm{T} / \mathrm{S}, \text { moral, } \\
\text { infrastructural and } \\
\text { information } \\
\text { dissemination }\end{array}$ \\
\hline
\end{tabular}




\begin{tabular}{|c|c|c|}
\hline & & \\
\hline $\begin{array}{l}\text { On CPD } \\
\text { policy }\end{array}$ & $\begin{array}{l}\text { Yes/no from belief on } \\
\text { existence (unaware, } \\
\text { doubtful), if there it is not } \\
\text { accompanied by funding.; } \\
\text { CPD practices exist within } \\
\text { provider local policies that } \\
\text { may link to presumed } \\
\text { policy through ministry } \\
\text { guidelines/benchmarks }\end{array}$ & $\begin{array}{l}\text { Twice as many schools have some form of CPD practice that can pass as policy from point of view of the } \\
\text { teachers } \\
\text { Teacher views of essence of CPD: } \\
\text { Refresher/updating to familiarize with current knowledge with aim of increasing competence } \\
\text { Holistic learning to grow (expertise, conduct, etc., all round) as a professional) to empower } \\
\text { Level deficits (upgrade qualifications, weak aspects of practice/knowledge) } \\
\text { Confidence boosting (master of content and related professional skills } \\
\text { Other insights: } \\
\text { Self driven (open mindedness, self assessing\& evaluating, awareness, enrichment) } \\
\text { No idea } \\
\text { Academic prowess in profession }\end{array}$ \\
\hline $\begin{array}{l}\text { Support } \\
\text { possibilities }\end{array}$ & $\begin{array}{l}\text { Schools and parents } \\
\text { (mostly PD related levies); } \\
\text { Donors (mostly in kind, } \\
\text { occasionally cash for CPD } \\
\text { projects); Self (cash); } \\
\text { Ministry (permissions and } \\
\text { operational grants to }\end{array}$ & $\begin{array}{l}\text { Relative frequencies of responses show that the bulk of CPD learning for teachers is supported by schools, } \\
\text { which get funding from the PTA or BSPZ which gets the funds from parents (directly or indirectly through } \\
\text { specific purposes levies on the learners. The support comes in one or combinations of T \& S or materials). } \\
\text { Some teachers acknowledge moral support or permission grants. The support may or may not be adequate } \\
\text { (depending on institutional capacity). } \\
\text { [Self sponsorship is quite prominent followed by NGO or private agencies and Ministry (often in form of } \\
\text { subsidized salary while the teacher is on study leave and the associated permissions and grants for the study } \\
\text { leave] }\end{array}$ \\
\hline $\begin{array}{l}\text { Overall } \\
\text { researchers, } \\
\text { observations }\end{array}$ & \multicolumn{2}{|c|}{$\begin{array}{l}\text { National policy provision on continuous capacity building through training for employees in all government ministries, teacher CPD } \\
\text { policy assumed in that framework. Top half tier of Ministry aware of that while bottom half (school level), teachers, and providers } \\
\text { unaware or doubtful of it as policy but acknowledge existence of CPD related guidelines and practices within Ministry. School's own } \\
\text { designed policy permitted if in conformity broad Ministry guidelines } \\
\text { Teachers conceptualize CPD as learning to upgrade or gap fill or re-fresher for specific purposes, including attaining higher qualifications } \\
\text { or confidence/status/competence boosting } \\
\text { Ministry has a miniscule CPD funding allocation on paper, on ground it relies on parents through school levies and on formal donor } \\
\text { partnerships. Many teachers self-fund or are subsidized in different forms including non-monetary by other sources including family, } \\
\text { schools, agencies, and when possible Ministry (e.g., enabling conditions). }\end{array}$} \\
\hline
\end{tabular}

Table 4 reveals that many teachers self-fund since ministry funding allocation is on paper but on the ground the ministry relies more on parents through official levies and formal partnerships with donor community. Teachers attend CPD activities to upgrade themselves, to obtain higher qualifications for boosting confidence, status, and competence. Table 5 presents information relating to the third research question on valuing of CPD learning.

\subsection{Research Question Three: Motivations for and Monitoring/Evaluation of CPD Activities}

Table 5. Annotated summary of informant responses about monitoring/evaluation and motivations for CPD activity.

\begin{tabular}{|c|c|c|c|c|c|}
\hline Source & Head office $(n=6)$ & Provincial $(n=4)$ & District $(n=10)$ & $\begin{array}{l}\text { Subject Inspector } \\
(n=4)\end{array}$ & School Head $(n=16)$ \\
\hline $\begin{array}{l}\text { On } \\
\text { motivations } \\
\text { and values }\end{array}$ & $\begin{array}{l}\text { Driven by desire for higher } \\
\text { qualifications that are linked } \\
\text { to higher salary (material } \\
\text { betterment); } \\
\text { Certification is a proxy for } \\
\text { higher attainments, few do it } \\
\text { for self development } \\
\text { (intrinsic) }\end{array}$ & $\begin{array}{l}\text { Teachers motivated by } \\
\text { prospects for career } \\
\text { movement through } \\
\text { higher qualifications; } \\
\text { Certification useful tool } \\
\text { for accounting learning } \\
\text { to others } \\
\text { Subject association also } \\
\text { source of motivation for } \\
\text { the intrinsic driven }\end{array}$ & $\begin{array}{l}\text { for personal development but } \\
\text { lack enthusiasm due to poor } \\
\text { incentives and depressed work } \\
\text { environment; } \\
\text { Enthusiasm can be raised by } \\
\text { appropriate incentives } \\
\text { including certification, (social } \\
\text { prestige) and higher } \\
\text { qualifications (socio-material), }\end{array}$ & $\begin{array}{l}\text { Desire to increase } \\
\text { competence to } \\
\text { secure levels; To } \\
\text { improve material } \\
\text { conditions } \\
\text { Psychological } \\
\text { satisfaction }\end{array}$ & $\begin{array}{l}\text { Self (higher } \\
\text { qualification and } \\
\text { material benefits } \\
\text { School (pass rates) } \\
\text { A few to be relevant } \\
\text { and up to date with } \\
\text { current trends in the } \\
\text { subject area }\end{array}$ \\
\hline $\begin{array}{l}\text { Monitoring } \\
\text { and } \\
\text { evaluation }\end{array}$ & $\begin{array}{l}\text { System structurally effective } \\
\text { but operationally ineffective } \\
\text { due to limited funding; } \\
\text { System integrates monitoring } \\
\text { and supervision (indirectly) } \\
\text { and operates at all cascade } \\
\text { levels }\end{array}$ & $\begin{array}{l}\text { CPD provisions not } \\
\text { formally evaluated it is } \\
\text { monitored through } \\
\text { observations and reports; } \\
\text { Province makes informal } \\
\text { judgment on } \\
\text { effectiveness }\end{array}$ & $\begin{array}{l}\text { Providers not formally } \\
\text { evaluated but monitored } \\
\text { indirectly through inspectorate } \\
\text { involvement in CPD as } \\
\text { participants, advisors and } \\
\text { evaluators of beneficiaries }\end{array}$ & $\begin{array}{l}\text { Pass rates used as } \\
\text { a measure for } \\
\text { effectiveness of } \\
\text { CPD activity }\end{array}$ & $\begin{array}{l}\text { [No comments } \\
\text { recorded on this } \\
\text { aspect] }\end{array}$ \\
\hline & $(n-0)$ & \multicolumn{4}{|l|}{ Teacher $(n=94)$} \\
\hline $\begin{array}{l}\text { On } \\
\text { motivations } \\
\text { and values }\end{array}$ & $\begin{array}{l}\text { Certification (for evidence } \\
\text { and accountability); } \\
\text { External (status work place } \\
\text { conditions) } \\
\text { internal (respect, valuing, }\end{array}$ & \multicolumn{4}{|c|}{$\begin{array}{l}\text { The teachers appear to be motivated by an urge to progress in their career (career mobility upward) which is } \\
\text { catalyzed by higher qualification and encouraged by easy access to the CPD venue. [This is for the majority]. } \\
\text { Fewer are motivated by a desire for personal self fulfilment (actualization) (internal) or by changing } \\
\text { employment conditions (policy expectations) (external). Fewer still are motivated by less personal and more } \\
\text { social related phenomena such as status (pride), pass rates, monetary/material benefits associated with higher }\end{array}$} \\
\hline
\end{tabular}




\begin{tabular}{|c|c|c|}
\hline Source & Provider $(n=6)$ & Teacher $(n=94)$ \\
\hline & $\begin{array}{l}\text { recognition, mastering of } \\
\text { subject, confidence }\end{array}$ & education \\
\hline $\begin{array}{l}\text { Monitoring } \\
\text { and } \\
\text { evaluation }\end{array}$ & $\begin{array}{l}\text { Generally informal by } \\
\text { provider, client, } \\
\text { supervisory section, peers, } \\
\text { externals in that order; } \\
\text { Methods: reflective } \\
\text { accounts e.g. } \\
\text { questionnaires, } \\
\text { observations, narrative } \\
\text { accounts, clients } \\
\text { performance, e.g. pass } \\
\text { rates) }\end{array}$ & $\begin{array}{l}\text { CPD learning is evaluated by formal tools/procedure (e.g.. exams) } \\
\text { As a large proportion of the CPD learning activity is associated with obtaining of higher formal } \\
\text { academic/professional qualifications. The other type of learning activity (dominated by workshop formats) is } \\
\text { not evaluated at all (certificates of attendance) } \\
\text { Occasionally there may be partial evaluation or self evaluation conducted } \\
\text { [The challenges for CPD learning have largely to do with paucity of resources. } \\
\text { Time limitations (both for implementing new ideas and for participating in CPD activities). The limitations } \\
\text { arises from heavy workloads in the main } \\
\text { Materials/facility (e.g. computers, internet, infrastructure) } \\
\text { Constraining work/practice environment (large classes, workloads, attitudes-learner, peer and sometimes } \\
\text { unsupportive admin) } \\
\text { Funding (for associated fees and services for the CPD)] }\end{array}$ \\
\hline
\end{tabular}

\begin{tabular}{ll}
\hline & CPD motivator for teachers largely career upscaling with its associated status and material betterment, in big part as a reaction to poor \\
material work environments. Higher paper qualifications are the mechanism for the movement. Fewer motivated by intrinsic calls (self \\
fulfilment, pride) or external (pass rates, employer rules). \\
Management encourages CPD for pas rates as proxy for institutional performance and prestige, while teachers value certification \\
(attainment or participation) as currency for social recognition or professional negotiating, and also for accounting the learning to others \\
researcher \\
observations
\end{tabular}$\quad \begin{aligned} & \text { No formal evaluation of most CPD provisions/activities; largely informal through observations, participation, teacher performances, } \\
& \text { participant reactions, provider activity and self-evaluation reports, etc. } \\
& \text { CPD provision monitored indirectly and in regular functioning through a cascading integrated monitoring-cum-supervision structures of } \\
& \text { the Ministry and providers such as higher education institutions. }\end{aligned}$

From Table 5 it is observed that evaluation of CPD activities is largely informal through observations, teacher performance, and participant reactions. It is also noteworthy that, while school management encourages CPDs for improvement in pass rates, teachers place a premium on certification.

\section{Discussion and Conclusion}

\subsection{Research Question One on Nature of CPD Activity (Table 3)}

Results in Table 3 show that the main form and format of CPD learning activity for Zimbabwean mathematics teachers was the short duration workshop during school time and occasionally longer duration during school holidays. For example, school heads mentioned workshops forty percent of the time as the main form of CPD activity. The workshops were usually initiated by the school, ministry organ, subject/professional association or donor partner. Short courses or longer course programmes normally done during holidays were mostly self-initiated and focused more on obtaining higher qualifications such as the bachelor or master of education degrees. School initiated activities were typically school sponsored, while sponsorship for teachers' own initiated activities was sometimes shared between self and a willing supporter or was carried fully by the teacher.

It can be observed that seminars, peer lessons, conferences, exchange visits, meetings, and group discussions may happen here and there per opportunity, but these were not the mainstay of CPD learning activity. Ministry district informants, for instance, produced the following relative frequency distribution for CPD activity modes: workshops (8), lesson demos/discussion groups (3), subject panel meetings (2), staff development meetings (3) short coursesat universities (4), and school exchange visits (2). It is also noted that almost all the activities take formal structure and operational characteristics; hardly any informal CPD learning platform such as individual networking or voluntary team teaching were mentioned by informants. Just to contrast, a CPD study in UK by Varga-Atkins et. al. [13] that explored the significance of interplay between learning networks and school-based collaboration found that the teachers there favoured school-based CPD activities more than networkedCPD platforms (including, by implication, institution based courses, workshops, seminars, etc.)

The sampled participants in the Zimbabwean CPD practice offered three main suggestions for improving their practice. All informants mentioned provision of CPD budget by the central ministry system from a variety of angles as their first suggestion for improving CPD learning. The unanimous suggestion that funds must be availed to enable CPD learning activity was followed by ideas that had to do with improving coordination and general efficiency of managing the activities, and acknowledging CPD learning in ways other than paper qualifications such as promotions, public citations, and material incentives. "Produce menus for CPD activities, provide international exposure for teachers, improve coordination of activities, give certificates of participation, involve teachers in CPD planning, make work environment inspiring, lodge ownership of CPD effort to the teacher client, teachers should develop a selfregulating capacity, and award points for CPD learning," were some of the suggestions for improvement offered by informants. These suggestions are inclined more towards operational aspects of the practice such as organization and management than to structural aspects such as 
inexistence of opportunity to learn.

\subsection{Conclusion on Research Question 1}

Data on the first research question summarized in Table 3 led to the conclusion that pathways for self CPD learning exist for mathematics teachers in Zimbabwe mainly in the form of formally orchestrated workshops in the field and courses or programmes in institutions of higher learning, and to a lesser extent in forms such as meetings, discussion groups, exchange visits, seminars. There are no formal structural blockages to teachers in this regard and if any obstacles are experienced, the obstacles would largely be of an informal nature and artefacts of malfunctioning of the system. Group or cohort based CPD formats, where cohorts of teachers are drafted into specific activities or programmes seem rare. Perhaps this is explained in part from the observation reflected in the data obtained that the teachers are largely self-driven, meaning they appear to have internal drive to willingly undertake CPD activity, although their stimulus/incentive may be external (higher paper qualifications and associated status/material feeling). 'They have zeal to learn," said one district officer; "They come to the workshops in their numbers when we invite them,' said a provincial officer, all acknowledging the drive the teachers appear to have. Whether they would retain the drive in more materially endowed working environments in the future can only be a matter of speculation.

\subsection{Research Question Two on Support for CPD Activity (Table 4)}

On the support dimension, it was noted that there was a standing national policy provision on continuous capacity building through training for employees in all government ministries, hence, if there is a teacher CPD specific policy it would be located within that framework. However, while the upper section of the ministry (provincial and head office) showed awareness of that policy guide, the lower tier (teacher, school, and district) and CPD providers were either unaware or doubtful of the existence of a CPD policy. "Yes, it is a constitutional requirement, Public Service Commission regulates such training for capacity building, people are allowed to self-develop, it is voluntary," a ministry head office officer explained; "Yes, it is implied, since there is a human resources division that overseas trainings at lower levels," said a provincial ministry officer; "If it is there, I am not aware of it, but I would say there is one for initial training," a provider at a tertiary institution admitted. The lower tier, however, acknowledged existence of CPD related guidelines and practices within ministry. "Yes and no, there are CPD practices for teachers, am not sure if there is a policy, the CPD practice has a weak resource base, there is a gap in fiscus for CPD," was how a provider from the Donor community put it. This view was endorsed by a provider from the tertiary institution who said, "As a teacher training department we contribute to CPD, but I can't link it to any policy I can think of." In addition, a school's own designed policy was permitted, even encouraged; it only had to be consistent with the broad ministry guidelines. A ministry district officer explained, "Yes, every district education officer is supposed to coordinate that aspect; policy is at subject level at districts." And yet another such officer said, "There is no policy at district, we follow a calendar of activities that we design," while a third officer remarked, "Schools are expected to have policy." Then, expressing the same yes/no feeing on existence of policy, one school head said, "School policy, yes, am not aware of national policy ..., if it is there I have not paid attention to it," and another added, "I have been looking for one .... I have not heard of any."

The teachers conceptualized CPD largely as learning to upgrade or gap-fill or re-fresh for specific purposes, especially attaining higher qualifications that bring with them greater confidence/status/competence: " Re-fresher courses to upgrade oneself, improving subject content and mastery, professional qualifications upgrade," some teachers wrote. Thus, the teachers' conceptualization of CPD was dominated more by a sense of learning to 'attain some social significance' than by a feeling of self-actualization. This somewhat restricted (strongly tied to higher qualifications) view of CPD was likely to impact on the teachers' perception of what counted as support, but nothing more than this can be said on this point. A similar observation on over-reliance on formal courses that lead to certification as the main mode of professional development for teachers has also been made in Lesotho by Moru, Qhobela, and Maqutu [22]. These authors recommend, too, that views on what counts as modes of professional learning need to be broadened to encompass 'collaborative teaching and learning at the work place, selfreflection, and reading a lot of research studies to see what other people elsewhere are doing in order to change their classroom practice for the better" (p. 261).

In terms of material support, what was clear is that the ministry had a miniscule CPD fund allocation on paper, in reality on ground it relied on parents through school levies and on formal donor partnerships. A ministry head office informant admitted, “... small fiscus budget, activities are sustained by support from parents and education partners [Donors] through institutionalized statutory instruments." Many teachers self-funded or were subsidized at different levels in different forms - including non-monetary-by other sources including family, schools, and agencies, to facilitate participation (e.g., withbus fares, room and board, workshop materials, and registration fees), and sometimes by the ministry (e.g., with enabling conditions such as study leave and related permissions). A relative frequency distribution on support modes drawn from teacher responses was: selfsupport (14), school/parents' school board (14), Donors (7), Ministry [non-financial] (3), family (2).

\subsection{Conclusions on Research Question 2}

There was an omnibus national policy provision for all government employees for training and re-training as necessary that many ground level people were unaware of. Each ministry contextualized that provision for itself and evolved a set of CPD-like locally regulated practices that 
many ground level people took to be the CPD policy. Each level, including the school, had the flexibility and freedom to craft their own local CPD policy which only had to resonate with the very broad parameters of the national guidelines and capacity building framework. And yet the ministry had no commensurate dedicated funding for meaningfully effecting desired CPD practices/outcomes. The ministry depends on, welcomes, and even exhorts parents, NGOs and other friendly bodies for assistance.

\subsection{Research Question Three on Monitoring Quality of CPD Provision (Table 5)}

The results indicate that there was no formal evaluation of most CPD provisions/activities; any evaluator insights would be largely informal and come through observations, participation, teacher performances, participant reactions, provider activity and self-evaluation reports, etc.CPD provision was monitored indirectly and during regular functioning of the cascade-style integrated monitoring-cumsupervision structures of the ministry and providers such as higher education institutions. "We monitor through observers we send to activities ... and facilitator (provider) reports ....," said a provincial officer, while one provider said, “..... through performance of teachers and participant self evaluation instruments ..."

As remarked earlier, a major CPD motivator for teachers to engage in CPD activity was the prospect of career upscaling with its assumed increase in socio-economic status. It appeared for the majority of the teachers that motivation was generated in big part as a reaction to poor material work environments. Again, relative frequency distribution of the teachers' responses on their motivators is consistent with this: career progression (44), accessibility of the training (26), higher qualifications (11), and personal fulfillment (11). A ministry district officer attributed low motivation of teachers to ".... poor incentives, but at the same time they like to get higher qualifications." Higher paper qualifications were the mechanism for the desired upward career movement. Fewer teachers were motivated by intrinsic feelings such as selffulfillment and pride or by external calls such as pass rates and employer rules. "They value CPD but are not selfstarters ... maybe due to discouraging work environment," asserted a ministry district officer. And a school head concurred, "...teachers are somewhat demoralized due to lack of meaningful incentives, but they like to self-develop... and CPD, especially when certified." Management encouraged CPD for raising pass rates-which they used as measure for their institutional performance and prestigewhile teachers valued certification for attainment or participation as currency for social recognition or professional negotiating, and, perhaps, for accounting the learning to self or others who may require it. Endorsing this, one school head said, "Teachers value further learning ... attend workshops even without certificates of attendance ... a school leadership that values CPD is a source of inspiration to teachers." And a ministry district official elaborated, "Teachers are driven by material incentives ... they generally sponsor themselves, the environment is depressed but they do not have to be persuaded ... they generally have the belief that if you are educated it is for life .... you will get more material rewards." A provincial level officer added his voice on the issue saying, "No problem of motivation whatsoever, they come on invitation, they would like to get higher qualifications, along with being better at their work .... Certificate is a tool for accounting the learning gains to someone else, e.g., funder, ..., but they should account to self as well, certificate or none."It could be interesting to know if the way the management and teachers value teacher CPD learning might relate with the prevailing style of monitoring and evaluation of CPD provisions, in which case a change in one may influence the other. This point will not be taken further here.

\subsection{Conclusions on Research Question 3}

It could be concluded that in Zimbabwe CPD provision was generally only informally evaluated through the integrated monitoring and supervision mechanisms of the education system in the course of its regular everyday functioning. This is to say there was no distinct and formal quality monitoring and evaluation regime specific for $\mathrm{CPD}$ learning activity. While motivations for teachers to do CPD were mixed - external and internal-but largely externally activated and internally nuanced, the evaluation of quality of CPD activity/provisions was almost an entirely internal matter of self-evaluation by both the client and provider.

\section{Implications}

a) The Zimbabwean maths teacher is technically - that is, conceptual-cum-structural-accommodated in terms of opportunities for self-CPD learning, but can't fully exploit the opportunity due to incapacity of the system to carry through its potentialities - a feature of operational malfunctioning.

b) The readiness of the mathematics teacher to engage in CPD learning is a strong $\operatorname{cog}$ in the Zimbabwean professional development terrain. The focus for the teacher, however, is only with formal learning platforms; the potential for CPD learning on informal platforms just for personal professional growth is yet to be activated in Zimbabwean context.

c) The paradoxical funding situation has potential for breeding undercurrents of tensions between expectations by ministry and those by ground level regarding the enabling of teacher CPD across levels. It is sort of like throwing ball at each other.

d) The mixed (internal drive /external stimulant) motivational scheme characterizing Zimbabwean mathematics teachers is a positive thing in the sense that they can potentially still willingly (though not enthusiastically) engage in CPD activity in absence of a stimulant - even in depressing environmental work conditions. However, the scheme is at the same time a negative thing in the way it rests on accounting for 
learning to external rather than internal sources-even in comfortable environmental work conditions.

e) "We function on trust,' said one provincial key informant on why they do not formally evaluate CPD providers. "We do informal judgments on trainings, but generally we believe the providers have done a good job, considering their reputation that we usually rely on," remarked a ministry district informant. These informant statements aptly capture a sense of provider and client working together in concert, buoyed by informal performance feedbacks to each other. That, however, places great responsibility of self-evaluation on clients and providers alike.

\section{Recommendations}

Based on the findings and discussion above, we make the following recommendations.

a) There is a clear need for Zimbabwean mathematics teachers to reflect and debate on the meaning of CPD at both personal and collective levels in order to broaden their understanding. Critical reflection on practice and knowledge will allow the teachers to develop ability to draw meaning out of students' thoughts during their teaching which consistent with Karsenty's [23] observation. Kennedy [24] asserts that critical reflection by teachers has rub-on effects which will develop among learners' abilities to interrogate their own and school practices. Forums where such interactions can occur include subject association meetings, the annual Bindura University conferences for science and mathematics teachers, and regular workshop forums, even school staff meetings. CPD, also, needs to be seen as more than an academic/professional practice and include a cultural dimension. The key to developing this view lies precisely in fashioning school environments (often led by the school management) that engenders the cultural character.

b) A study by Mtetwa et al. [2] revealed that CPD learning is more of a personal and voluntary than group and mandatory matter for Zimbabwean teachers The system tries to provide enabling mechanisms (technical pathways and emotional support). The retaining of this teacher autonomy but with an injection of adequate material, especially funding, and psycho-social support (recognition) support to make the system more functional and effective is recommended. Pass-rates as the standard measure for effectiveness of the work of teachers is also rather narrow; teachers should be recognised for producing mathematically literate and well rounded learners.

c) The cascade-style integrated monitoring-cumsupervisory configuration of the ministry, along with the ministry's orientation of giving the lower tiers leeway in crafting their own CPD practices that only need to be in tandem with the overall broad ministry vision of providing quality education to the Zimbabwean child, gives the whole system a dual centralized-decentralized orientation. That is not bad in and of itself; what all players in it need to do is ensure that the bearing of that orientation is complementary and conflict-free. The Zimbabwean system appears to have a potential to achieve that, especially if it remedies malfunctioning operational aspects that are real sources of conflict between the two tendencies.

The paper ends with a speculation on whether the doubt in or unfamiliarity with the existence of a formal national CPD policy evident among ground level players arises from inadequate within-system dissemination or it is the continuous capacity building provision national statement that is, in and of itself, inadequate to function as effectively as a specially formulated teacher CPD policy would. It is noted, however, that CPD practices/activities happen in spite of the perceived absence of a CPD policy or ignorance by many players of the presumed existence of a CPD policy. But, perhaps, anew specially crafted well disseminated CPD policy could bring in the needed operational efficiency, but we leave this open for consideration.

\section{Acknowledgements}

The authors are appreciative of UNISA through the Department of Mathematics Education, College of Education, for the enabling fund to carry out the study; Zimbabwe Ministry of Primary and Secondary Education for granting us permission to access their personnel at all levels of the system; our key informants: the teachers, school heads, district officers, provincial officers, and head office educators who willingly availed themselves for our probes; and inservice education providers (NGO education partners and department chairpersons at educational institutions) who talked to us about their offerings to mathematics teachers in practice in the field.

\section{References}

[1] CPD Unit. Notes on the CPD system. University of Namibia, 2013.

[2] D. Mtetwa, B. Chabongora, Z. Ndemo, and E. Maturure, Features of continuous professional development (CPD) of school mathematics teachers in Zimbabwe, International Journal of Educational Sciences (IJES), 8 (1-ii), (2015), 135-147.

[3] SEITT Project Document, Science education in-service teacher training (SEITT) project, 1994 -1998, Department of Science and Mathematics Education, University of Zimbabwe and Free University, Amsterdam, (1993).

[4] K. Chavunduka, Improving science education in Zimbabwe: The role of resource teachers in professional development. Enschede: University of Twente, (2005).

[5] M. K, Abreh, Heads of departments' perception of teachers' participation in continuous professional development programmes and its influence on science and mathematics teaching, African Journal of Educational Studies in Science and Mathematics, 14 (2018), 85-99. 
[6] G. K. B, Gomba, Challenges faced by educators in the implementation of continuing professional teacher development (CPTD): Gautenge Province, In R. Monyai (Ed.), Teacher Education in the $21^{\text {st }}$ century, InterTech, (2019).

[7] W. M. Si, Study on the continuous professionalism development of mathematics teachers in junior high school in Indonesia, International Journal of Education and Research, 2 (8) (2014), 293-309.

[8] J. WeiBenrieder, B. Roesken-Winter, S. Schueler, E. Binner, and S. Blömeke, ScalingCPD through professional learning communities: development of teachers' self-efficacy in relation to collaboration. Mathematics Education, 47 (2015), $27-38$

[9] B. Roesken-Winter, C Hoyles, and S Blómeke, S. (2015). Evidence-based CPD: Scaling up sustainable interventions. ZDM- Mathematical Education, 47 (2015), 1-12.

[10] A. Bandura, Self-efficacy: toward a unifying theory of behavioral change. Psychological Review, 84 (1977), 191-215.

[11] M. Sapt, E. B. Irawan, A. R. As'ari, C. Sa'dijah, Susiswo, and A. Wijaya, Comparing model-building process: A model prospective teachers used in interpreting students' mathematical thinking, Journal on Mathematics Education, 10 (2), (2019), 171-184.

[12] N. Mansour, H. EL-Deghaidy, S. Alshamrani, and A. Aldahmash, Rethinking the theory and practice of continuous professional development: Science teachers' perspectives. Research in Science Education, 10 (2014), 65-84.

[13] O. Varga-Atkins, M. O’Brien, D. Burton, A. Campel, and A. Qualter, The importance of interplay between school-based and networked professional development: School professional' experiences of inter-school collaborations in learning networks, Journal of Educational Change, 11, (2010), 241-272.

[14] A. S. Sabah, M. Fayez, S. M. Alshamrani, and N. Mansour, Continuing professional development (CPD) provision of science and mathematics teachers in Saudi Arabia: Perceptions and experiences. Journal of Baltic Science Education, 13 (2) (2014), 91-104.
[15] J. Sachs, Learning to improve or improving learning: the dilemma of teacher continuing professional development. Proceedings of the 20st Annual World ICSEI conference, (2007).

[16] A. Kennedy, Models of continuous professional development: A framework for analysis. Journal in Science Education, 31 (2) (2005), 235-250.

[17] A. Joubert, J. Back, E. De Geest, C. Hirst, and R. Sutherland, Professional Development for teachers of mathematics: Opportunities and Change. Proceedings of CERME 6, France, (2009).

[18] L. M. Mokhele, and C. L. Jita, South African teachers' perspectives on continuing professional development: A case study of the Mpumalanga Secondary Science Initiative. Procedia Social and Behavioral Science, 9, (2010), 1762-1766.

[19] J. H. MacMillan, and S. Schumacher, Research in education: A conceptual introduction (5th ed.). New York: Longman, (2001).

[20] N. K. Denzin, and Y. S. Lincoln, The Sage Handbook of Qualitative Research. Third Edition. Thousand Oaks: Sage, (2005).

[21] K. Maree, First steps in research. Van Schaik Publishers, (2012).

[22] E. K. Moru, M. Qhobela, and T. Z. Maqutu, T. Z. (2014). The impact of instruction in enhancing teachers' knowledge of teaching mathematics in some Lesotho primary schools, Teacher Development, 18 (2) (2014), 246-263.

[23] R. Karsenty, Professional development of mathematics teachers: Through the lens of the camera, In G. Kaiser et al. (Eds.), Invited Lectures from the $13^{\text {th }}$ International Congress on Mathematics Education, Hamburg University: Hamburg, (2018), 269-288.

[24] A. Kennedy, Looking beyond the obvious: Applying a critically reflective lens to professional learning literature, Professional Development in Education, 45 (4), 523-526. 